\title{
LOPE DE VEGA AND THE CONQUEST OF SPANISH THEATER IN THE NETHERLANDS
}

\author{
Frans R.E. Blom and Olga van Marion \\ (Universiteit van Amsterdam / Universiteit Leiden)
}

Cita Recomendada: Frans R.E. Blom y Olga van Marion, "Lope de Vega and the Conquest of Spanish Theater in the Netherlands», Anuario Lope de Vega. Texto, literatura, cultura, XXIII (2017), pp. $155-177$.

DOI: < http://dx.doi.org/10.5565/rev/anuariolopedevega.194>

Fecha de recepción: 14 de marzo de 2016

Fecha de aceptación: 3 de mayo de 2016

AbSTRACT

This contribution focuses on Lope's conquest of Amsterdam's grand theater in the 40s and 50s of the seventeenth century. Focusing on creative industries, we analyze the producer's side for Lope's "invasion" in the Netherlands, and the channels that were developed in order to faciltate the new Spanish productions for the Amsterdam theater. Focusing on the consumer's side, we measure, both qualitatively and quantitatively, the successes (and some failures) of Lope's plays. In our new data base ONSTAGE, that gathers information about plays, performances and companies' revenues, we show convincing evidence that Lope was the most popular playwright in those years in Amsterdam, even more popular than our local playwrights. The article is completed with an inventory of all of Lope's plays adapted for the Amsterdam stage. We hope these new findings may contribute to a more complete picture of Lope's European career.

KEYwords: Lope de Vega; Netherlands; theater; creative industry; cultural transfer.

\section{RESUMen}

Esta contribución se centra en la conquista del gran teatro de Ámsterdam en los años 40 y 50 del siglo XVII por parte de Lope. En una aproximación a las industrias creativas, se analiza el lado del productor para entender la invasión de Lope en los Países Bajos, y los caminos de transferencia que se desarrollaron con el fin de facilitar las nuevas producciones españolas para el teatro de Ámsterdam. Por el lado del consumidor, medimos, de forma tanto cualitativa como cuantitativa, los éxitos (y algunos fracasos) de las obras de Lope. En nuestro nuevo sistema de datos ONSTAGE, sobre obras de teatro, puestas en escena e ingresos, evidenciamos que Lope fue el dramaturgo más popular en esos años en Ámsterdam, aún más popular que nuestros propios dramaturgos. Al final, el artículo tiene un inventario de todas las obras de teatro de Lope redefinidas para la etapa de Ámsterdam. Esperamos que estos nuevos hallazgos puedan contribuir a una imagen más completa de la carrera europea global de Lope.

Palabras Clave: Lope de Vega; Países Bajos; teatro; industria creativa; transferencia cultural. 


\section{INTRODUCTION}

Eighty years of war against Spain eventually brought freedom and autonomy for the United Provinces of the Netherlands in 1648. The final conclusion of peace between the two former enemies introduced a new era of traffic, trade and exchange. Now, instead of military campaigns, time was ripe for cultural confrontation: in two decades Spanish theater invaded the Dutch realm and gloriously conquered the people's taste in the Netherlands.

Most favorable to the success of the Spanish breakthrough was the institution of the Amsterdam City Theater. The first permanent and public theater built in the Netherlands in 1637, was so much of a novum that the Dutch even invented a new word for it, and named it the Schouwburg. ${ }^{1}$ Located in the recently developed and most prestigious canal belt at the Keizersgracht 384, the theater was the beating heart of Amsterdam's cultural life and the permanent and physical home base for a widespread urban network of people involved in the creative industry of performing arts. First of all, and much unlike the touring theater companies in Europe, this was the place where a local company of about twenty actors, singers and musicians worked all year around, on the basis of annual contracts. Then, in preparation of the performances, another circle of craftsmen and artists would produce costumes, props, posters, pamphlets and tickets, candles to light up the hall and stage, and personal needs like pens, herrings and beer. Moreover, the ever busy Amsterdam printing houses would provide each individual performance with authorized (and sometimes unauthorized) printed text books on sale at the entrance. ${ }^{2}$

With plays on stage twice a week, the prestigious Schouwburg, of course, was a splendid opportunity for playwrights, as it generated a great demand for

1. An English introduction to the Amsterdam Schouwburg is Brandt [1993]. Key studies in Dutch are Worp [1920], Kossmann [1915], Albach [1977], Smits-Veldt [1991].

2. Bibliographical data on all printed Dutch texts prior to 1800 is available in STCN see http:// www.stcn.nl. Some of the works are in Google Books. For academic standards and high quality scans, a broad selection of primary sources is published on the internet site Early European Books Online, see http://eeb.chadwyck.com/home.do. 
new drama productions. In fact, it required a successful and attractive repertoire to be built up from the first show day on. Some of these plays were taken from the repertoires of the local Chambers of Rhetoric, i.e. the literary societies that had organized most of the city's cultural events so far and eventually merged into the new professional theater. Members of Amsterdam's two Chambers of Rhetoric had been producing plays, on a much smaller scale, in the previous decades. Other productions, especially in the genre of farces, would be newly invented by so many local actors and playwrights. But most characteristic for all creative industries of seventeenth century Amsterdam, and for the city theater in particular, was the fact that the new repertoire was connected to Europe. In an ever increasing flow of new productions, the Schouwburg adopted and adapted theater productions from all different 'national' theater traditions. In fact, the innovation of appropriating international successes for a Dutch audience proved the back bone for the repertoire, as these plays were generally much appreciated by the people. And, maybe even more importantly to the institute's Directors, they generated relatively high revenues. ${ }^{3}$ For, not unlike so many other European theaters, the Amsterdam Grand Theater was developed not only for the city's cultural prestige but also as a financial profit model for charity and social sustenance. So, money was the thing in this cultural enterprise. And, as with all creative industries, one of the safest and most guaranteed ways of being successful in that matter, was to rely on proven foreign hits, such as the plays of the renowned Spanish playwright Lope de Vega.

As far as we have been able to identify the international plays, Spanish theatre tradition of the Siglo de Oro is strongly present in Amsterdam's repertoire with a total amount of 58 productions. ${ }^{4}$ In this Spanish corpus, twenty plays are by Lope de Vega. They rank among the most popular Spanish adaptations as well as the earliest ones. The transfer history indicates that Lope's cultural invasion of the Netherlands was just waiting there to cross borders as soon as military confrontations would stop. Already at the beginning of the $17^{\text {th }}$ century, the temporary seize fire of the Twelve Years Truce of 1609-1621 created a first momentum. This time frame,

3. Translations and adaptations, often of foreign successes, would come to constitute 65 per cent of the Schouwburg repertoire, see Brandt [1993:339].

4. For an inventory and analysis of the cultural transfer of Spanish theater to the Amsterdam theater, see Jautze, Álvarez and Blom [2016]. 
indeed, offered a chance for cultural transfer, when the Amsterdam diplomat Theodore Rodenburgh, who as a poet and playwright was also a pivotal figure in the city's cultural life, travelled the Iberian Peninsula for business purposes in 1616. On his return, Rodenburgh was the first Dutch playwright to produce adaptations of Lope de Vega plays for the Chambers of Rhetoric in Amsterdam. ${ }^{5}$ When the war was resumed, however, his adaptations remained the only Spanish plays in Amsterdam for the next three decades. Only by 1645 , as serious peace negotiations preluded the final conclusion of the war, the transfer window was reopened. And this time, with the new Grand Theater up and running, demands were high to enhance its 'native' repertoire by translating and producing the attractive Spanish plays on an industrial scale.

The Dutch audience loved and never stopped loving Spanish plays ever since the first Amsterdam adaptations were staged in the Grand Theater. Along with some of his fellow playwrights like Calderón, Mira de Amescua, Rojas Zorilla and Ruiz de Alarcón, Lope de Vega's plays were really en vogue in the city. In a concentrated period of two decades most of the twenty plays were taken from his oeuvre, and produced for Dutch eyes and ears. (For a full list see the annex to this article.) Moreover, Lope de Vega was so much embraced by the audience, that many of these works were to stay and dominate the repertoire for over 150 years. In productions for the Amsterdam Schouwburg, Spain's number one playwright easily surpassed

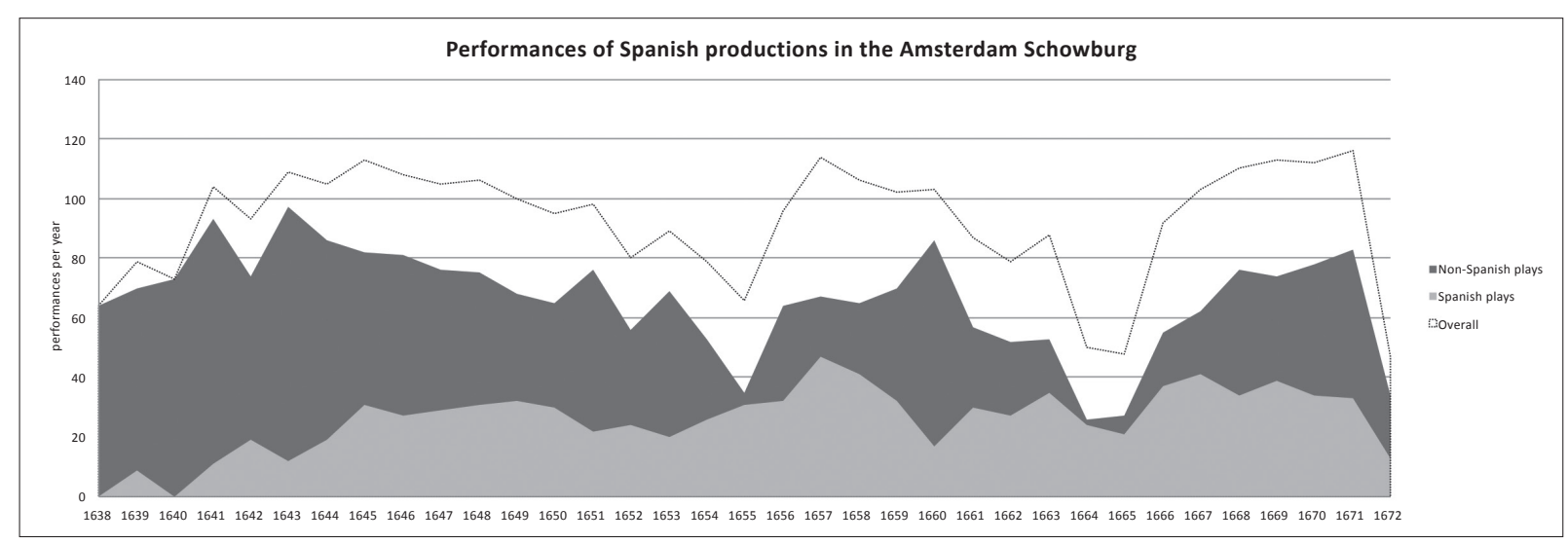

Illustration 1: Spanish productions as part of the annual repertoires of the Amsterdam Theater, 1638-1672, based on ONSTAGE. From: Jautze, Álvarez and Blom [2016].

5. For Theodore Rodenburgh's adaptations of Lope de Vega plays see Marion and Vergeer [2016]. 


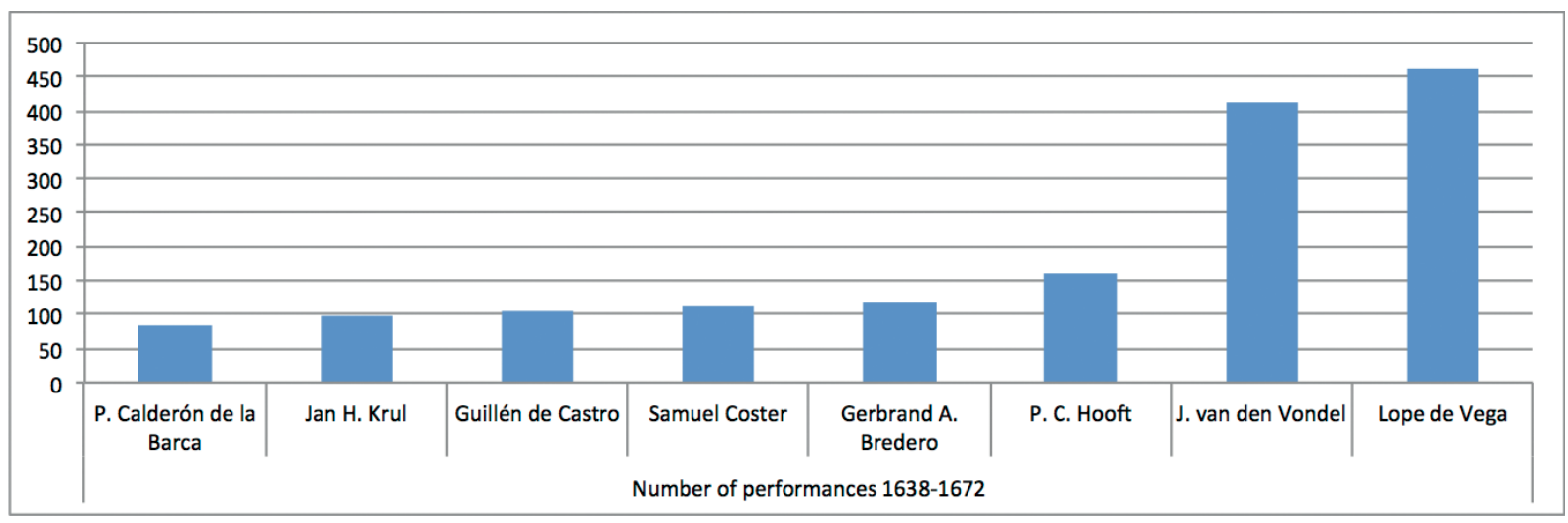

Illustration 2. Cumulative Schouwburg-performances per playwright, Spanish top and Dutch top, 1638-1672 (Guillén de Castro is represented by the French play of Le Cid). Based on ONSTAGE. From: Jautze, Álvarez and Blom [2016].

local playwrights. And even the city's home grown theater hero at the time, Joost van den Vondel, was only second in popularity and revenues.

This contribution tells the fascinating story of how Lope de Vega invaded and conquered the Dutch domain. We aim to give an analysis of the industrial import of his plays for the Amsterdam theater. As such, this study deals with production processes for the theater. Moreover, we will also assess the consumer's side in this particular creative industry, and measure the popularity of Lope de Vega's various plays in Amsterdam. For that purpose, we analyze the extensive information about performances and revenues as it has come down to us in the contemporary theater administration, which has recently been made accessible through the online data system ONSTAGE. ${ }^{6}$

\section{ENTER Lope DE VEGA}

When the Grand Theater of Amsterdam was taking off in 1638, the repertoire was all but strong and diverse. Although the doors opened on 65 show days during that initial year, there were only ten different productions on stage. By lack of alternatives, quite a few plays got programmed for over ten times in a row. However, the

6. The online datasystem for the Theater of Amsterdam in the Golden Age (http://www.vondel. humanities.uva.nl/onstage/) is an initiative by Frans R.E. Blom and is hosted at the University of Amsterdam. 
poor situation was soon to improve, as in those years Spain entered the stage, adding lots of variety to Amsterdam's repertoire and thus creating a new consumer's taste.

Lope de Vega was the front man of the Spanish invasion in the Schouwburg repertoire. Undoubtedly, the Amsterdam Theater was eager to produce his oeuvre most and for all, as the playlists show. ${ }^{7}$ In 1642 , the first Spanish play ever in the Schouwburg was the staging of Casandra en Karel Baldeus, the Rodenburgh adaptation of Lope's El perseguido. After its premiere in the local Amsterdam Chamber of Rhetoric in 1617, it had never ceased to be popular. And now, as the first Lope play in the Grand Theater, it proved an innovation and a major contribution to the repertoire. Number one hit of the year, it was staged 15 times on the total amount of one hundred shows (and it was to stay a successful part in the program for thirty years). No wonder that the theatre continued to produce Rodenburgh's adaptations of Lope de Vega, when, two seasons later, it also adopted La escolástica celosa in the repertoire. On the long run, this second Lope play, entitled Jaloersche studenten, may have been less successful than its predecessor, but it still had five performances in 1644 and another five in the next two years.

While both Lope de Vega adaptations by Rodenburgh gave the crowds in Amsterdam a first taste of Spanish drama qualities, the theater directors must have been charmed, surely, by the increasing numbers of visitors, too. More attractive plays and a wider variety caused the revenues to be steadily rising for these years. However, with Rodenburgh's adaptations in use now, the next challenge was how to expand on the successful innovation of Spanish theatre in the Schouwburg. The production process, in whatever way, faced some serious challenges in dealing with the source materials. For, who was a connoisseur of Spanish theater at the time, and who had the knowledge to select the proper works from Vega's oeuvre? Moreover, who was able to carry out the transfers from his texts to the Amsterdam theater? As a multilingualist, Theodore Rodenburgh had been a single and unique white raven up to then, when, sadly, he passed away in 1644. Surely, one of the major obstacles in the transfer process was that hardly

7. The only Spanish play in Amsterdam prior to Lope is the Cid. In 1641, it was staged in the Dutch version by J. van Heemskerck, based on the famous play Le Cid by Corneille (1635). A major hit in Amsterdam's repertoire, it was introduced as a French play, even though Corneille had adapted the Spanish original by Guillén de Castro. 
anyone in Amsterdam's theater production circles mastered the Spanish language.

\section{The French CONNECTion}

One solution to the problem was created from within the circle of actors, in the transfer path as it was developed for the next Spanish play. In 1645, the Schouwburg proudly staged the third Vega comedia in a row. This was the Laura persegui$d a$ or in Dutch Vervolgde Laura. Unlike its predecessors, which had been staged in the Chambers of Rhetoric before, the Laura was a brand new production, exclusively made for the new theater to enhance its repertoire. In rimed and paired verses of jambic hexameters or alexandrines, so characteristic for Dutch play texts at the time, the Dutch version of the Laura was composed by Adam Karels van Germez. This author, although his geographical nick name Van Germez might sound foreign, and even Spanish, was a native Amsterdammer, and a well known person, too. Van Germez, also known as Mr. Adam among the crowds, was one of the Grand Theater's top actors.

As a stage man, Van Germez had personally been involved in performing both previous Lope plays in the Schouwburg, and now he was presenting a new text by the great Spanish playwright, all done by himself. ${ }^{8}$ The transfer, as his introduction to the play text tells, had been far from easy: Mr. Adam did not understand a word of Spanish. Even worse, as with all of the actors in the Amsterdam company (most of them of rather humble descent) the only language he mastered, was his mother tongue. Therefore, his source was a Dutch prose translation of the French adaptation, entitled Laure persécutée, by Jean Rotrou. ${ }^{9}$

With the very first Spanish production made for the Schouwburg, Van Germez really had some serious start-up problems in presenting his Vervolgde Laura. The title page of the work did not mention Lope de Vega as the author, nor did it

8. In Rodenburgh's Jaloersche studenten, Van Germez played the role of Valerio; his part in Casandra en Karel is unknown. See Worp [1920:111].

9. A first taste of the Laura was given to Van Germez by the Amsterdam writer Kasper van Baerle, who, as Van Germez tells in the introduction, had rendered a selection of 300 verses in Dutch. See Germez [1645:fol. *6v]. 
refer to any Spanish source at all. In fact, the work as it was presented, looked like a creation by Van Germez himself, as it was his name, exclusively, that starred on the new play text. This triggered some rival playwrights in Amsterdam to raise their voices in an immediate wave of enmity and defamation of the work and its Dutch author as soon as it came on stage. Van Germez was urged to react to what he said was an unjust persecution of his innocent Laura, and added an apologetic dedication to the publication some weeks after.

Explicitly focusing on the provenance of his production, the dedication of the Laura is very informative about the do's and don'ts in transfer processes of Amsterdam's creative industry. First of all, it seems, a Dutch actor and playwright working with foreign sources should not keep all credits to himself. In some way or another, people should be informed about borrowed goods. Van Germez, therefore, admits in the introduction that this play «is not my own invention, but it is Rotrou, in my verse interpretation based on the work by Jan Hendrik Glazenmaker, who provided me with a prose translation, unpaid for and in friendship. Also, I should mention the friendship of mr. Kasper van Baarle, who had already translated 300 verses for me, quite a while ago, making me excited about the play in the first place». ${ }^{10}$ With these three intermediaries mentioned by name, Van Germez publicly degraded himself from the status of auctor intellectualis or authentic poet or playwright, to that of a rijmer, or versificator, who just contributed at the end of the production process. Moreover, Van Germez admits that it was a faux pas of haughtiness, indeed, not to mention Lope de Vega as the prime inventor. If any, the only excuse he could offer, was that his French intermediary had done likewise:

The arrogance of putting my name alone on this work, I have learnt from my example Rotrou, when he brought this play from the Spanish by Lope de Vega into French, as I had to do from French into Dutch. ${ }^{11}$

10. Quoted, in English translation by the authors, from the introduction to Vervolgde Laura by Germez [1645:fol. *6v]: «Maar [ik] vertoon U Rotrou, of vertolk hem in rym, naa dat hy my eerst van Jan Hendriksz Glazemaker in 't rymloos van woord tot woord uyt liefde vertaald is. Voor welke genegenheyd tot my en den Armen, ik hem eeuwiglyk betoonen zal dankbaar te zijn».

11. Quoted, in English translation by the authors, from the introduction to Vervolgde Laura by Germez [1645:fol. *7r]: «De hoovaardy evenwel van mynen naam hier alleenig boven te zetten, heb ik geleerd van mynen Meester Rotrou, die 't zelfde in Frans uit het Spaens van Loopes de Veego [sic] gedaen heeft», The point is stressed in the laudatory sonnet by Van Germez's friend and fellow actor Leon de Fuyter in the introduction. The final line of the poem explicitly praises him a 'sweet voiced 
For all its social shortcomings and damage repairs, the transfer method that Van Germez had applied to bring the Laura perseguida on stage in Amsterdam, proved worth the effort. The Laura, indeed, was a major contribution to the Spanish coloring in the repertoire. In 1645, after staging Kasandra en Karel and Jaloersche studenten (both in February), the Schouwburg presented Vega's third play in March. It was so well received that it remained on stage with no less than 12 performances during that year. For almost thirty consecutive years, the Laura was alive in the theater repertoire with three to four annual performances.

So, in addition to the adaptations by the diplomat Rodenburgh, who had been in Spain and transferred the plays all by himself, a new transfer road for Lope de Vega and other Spanish theater plays towards Amsterdam was opened along the route of Laura perseguida. The route would pass through a French intermediary drama text (such as Rotrou's Laure persécutée, 1637) into a Dutch prose text, before ending up in the Dutch rimed drama version by a local theater actor like Van Germez. ${ }^{12}$ Another Lope specimen among the Spanish plays following this transfer way, is Las mudanzas de fortuna y sucesos de Don Beltrán de Aragón. It became known as the play Kosroes (1656) in the Dutch version by the Amsterdam actor Adriaan Bastiaansz de Leeuw, after the French intermediary of Jean Rotrou's Cosroes.

In a detour, some Spanish plays on this 'intermediary' route entered the Dutch speaking realm not in Amsterdam, but more to the south, in Brussels or Antwerp, first. There, they would be converted into the charming Brabant dialect of Dutch language for local performances. And when very successful, occasionally they could continue their way up north in order to be slightly adapted to the northern Netherlandish tongue for the Amsterdam Schouwburg. This, for sure, has been the case

translator' rather than a playwright ('zoetvloeyende Vertaalder'). An interesting parallel case occurred when the playwright Thomas Asselyn's produced Grooten Kurieen (1657, the adaptation of Lope's play La amistad pagada). He was accused of not mentioning that his work was based on a Spanish original: "which was done by the versificator of the Grooten Kurieen, who introduced it as his own play to the people, hiding its Spanish source. But, most probably, he paid for the translation, so that he felt free to consider it his own». Quoted (in English translation by the authors) from Lodewijk Meyer 'Verdeediging van de Verloofde Koningsbruidt'. In: Antwoordt op het voor- en nabericht, By de Antigone gevoegt door N.N. en E.B.I.S.K.A, Amsterdam, 1670, p. 29: «gelijk de Rymer van den Grooten Kurieen gedaan heeft, die dat Spel den onweetenden voor 't zijne in de handt steekt, verzwijgende, dat het uit het Spaansch is. Doch hy heeft moogelijk de vertaaling betaalt, en reekent het daarom voor 't zijne».

12. For an overview of Spanish theater productions in France see Losada-Goya [1999] and the inventory by Horn-Monval [1961]. 
with a few productions by the Brussels playwright Claude de Grieck. Three of his Spanish adaptations were restyled by Amsterdam actors for the Schouwburg, although none of them derives from the Lope de Vega oeuvre. ${ }^{13}$

\section{The SEPHARDIC CORRIDOR}

Going back now to the initial phase, the Spanish innovation was taking place at the steady pace of one new addition to the repertoire per year. Moreover, the popularity and success is underscored by their relatively frequent performances. By 1645 , the three Vega plays added up to 18 performances, which is 20 percent of that year's overall play list of a approximately one hundred performances. It may not surprise, then, that more Spanish plays were wanted, and an additional transfer way was paved, shortly after. The royal road for Amsterdam's creative theater industry to import works by Lope de Vega into the Dutch theater, was developed in an innovative project that was to follow up on Laura and presented number four in the annually growing line up of Vega's plays.

In 1646, it was El amigo por fuerza that really captured the Dutch audience, with tremendous and long lasting success. It became widely known in its translated title of Gedwongen vrient. ${ }^{14}$ This production, again, was done by one of the local actors in the Amsterdam company. But, clearly, the actor and playwright Isaac Vos had learnt from the problems caused by Van Germez's transfer of the Laura. Now, the title page of Gedwongen vrient puts things in the right order. On top, Lope de Vega features as the author, while, in second place, Isaac Vos is mentioned as the one responsible for rendering this play into Dutch riming verses ('in Duyts gerijmt', see Illustration 3).

13. Spanish plays imported from the Southern Netherlandish theater tradition are Claude de Grieck's Don Japhet van Armenien (Castillo Solórzano's El marqués del Cigarral), Den grooten Bellizarius (Amescua's El ejemplo mayor de la desdicha) and Cenobia (Calderón's La Gran Cenobia), and one play by Schouwenberg, Sigismundus, prince van Polen, of 't Leven is een droom (Calderón's La Vida es Sueño). See also Jautze a.o. [2016]. The most prolific adaptor of Lope de Vega's work in the Southern Netherlands is Cornelis de Bie from Lier (1627-1715). His plays, however, did not make it to the Amsterdam Schouwburg. For his Lope adaptations see: Jans [1929].

14. For some more details see Álvarez Francés [2013]. 


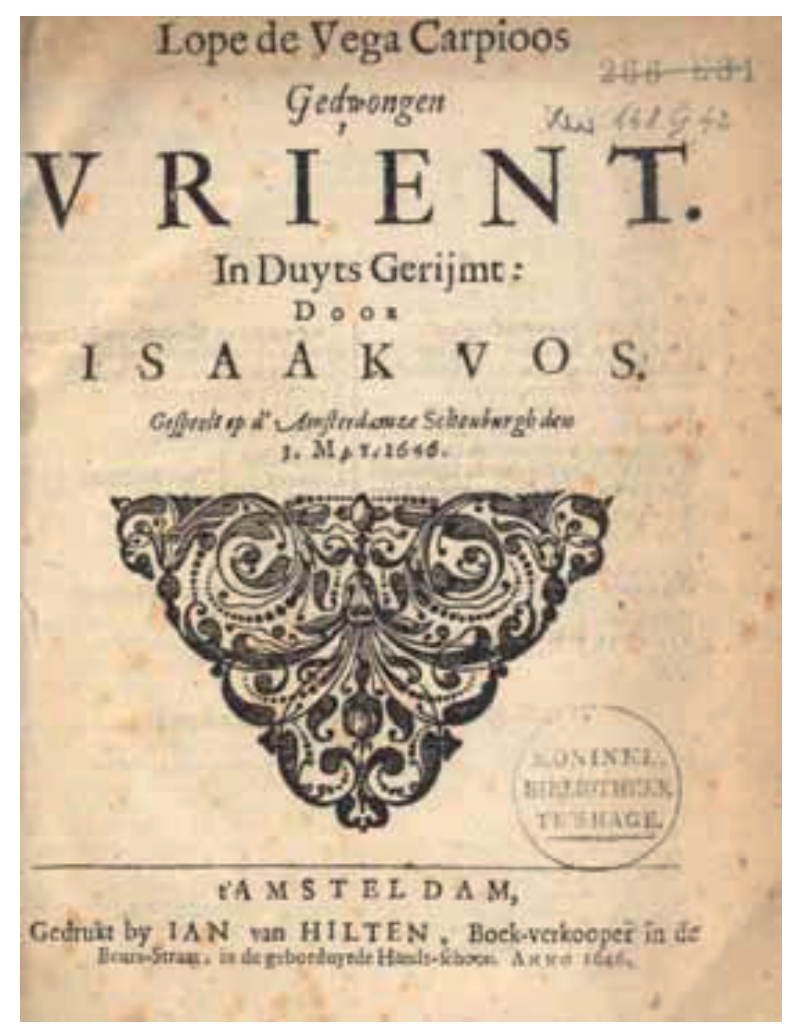

Illustration 3: El amigo por fuerza as it was performed in the Amsterdam Schouwburg in the Dutch version by the actor and playwright Isaac Vos.

Now, for Lope's El amigo por fuerza there was no French version existent in print, nor had it been staged in France before Isaac Vos laid his hands on the play. So, how could Vos ever know about this play and carry out the transfer of Gedwongen vrient? Very much like his friend and fellow actor Van Germez, Isaac Vos did not speak or read any other languages than Dutch. But different from the French route, he found a helping hand close by, in the Amsterdam community of Sephardim. Immigrants from the Iberian peninsula, the Sephardim were a population of approximately one thousand people in the city at the time, cultivating, of course, a vivid connection to Spanish language and culture. Moreover, they had a vivid Sephardim theater culture in Amsterdam, that seems to have been connected strongly to the Iberian theater tradition. ${ }^{15}$ But, how did the Sephardim come into view as a transfer road for Spanish play texts to the Amsterdam City Theater? Some histo-

15. Boer [1992:165-168 and 311-351], and also Praag [1922]. 
rians have liked to point out that the Sephardim in Amsterdam clustered together in one geographical area on the other side of town (Vlooijenburg), thus living in a community that was kind of isolated from the city's 'native' social and cultural life, in those days. Accordingly, the Sephardim would have had a rather passive attitude in learning the Dutch language. ${ }^{16}$ However, the Jewish transfer route for the Schouwburg tells a different story, and indicates that at least some of these migrants made an essential contribution to the city's cultural life, and accordingly were highly esteemed. That is surely the case for Jacobus Baroces, the Sephardic Jew who proves to have been the conditio sine qua non for the Amsterdam productions of, at least, eight Spanish plays, among which five by Lope de Vega.

The print edition of Gedwongen Vrient has a dedicatory introduction by Isaac Vos that, not unlike the Laura, deals extensively with the transfer topics of initiative, inspiration, and intermediaires. Most generously, it gives credits both to Lope de Vega as the creative genius of the play, and to Jacobus Baroces, who, in fact, is said to have opened Vos' eyes for the qualities of Lope's play by presenting his prose translation of El amigo por fuerza to the actor and playwright in order to make it a new production for the Schouwburg:

My [i.e. Isaac Vos's] eyes met with the spirit of the deceased but ever to be remembered Apollo of Madrid, the great Spanish poet Lope de Vega Carpio. Resurrected and brought to life by the art loving and hard working sir Mr. Jacobus Baroces and while gliding on Dutch wings he appeared and stirred up and forced his friend of the same tongue to hand over the Dutch version of his El amigo por Fuerza to me, in order to bring it to life on the Amsterdam Schouwburg in Dutch verses. ${ }^{17}$

In the city's archives, unfortunately, Jacobus Baroces has left only a handful of traces about his life. From the matrimonial records we learn that in 1651, at the age

16. For trading purposes, Amsterdam Sephardim mastered the Dutch language at least on an elementary level. Writing skills in Dutch, however, were not part of their educational curriculum, see Fuks-Mansfeld [1989:107-109] and Bodiam [1997:67].

17. Quote (in English translation by the authors) from the dedication of Isaac Vos' Gedwongen Vrient (Vos 1646): «my [is] de Geest van den verstorven doch eeuwigh in heughnis levenden Madritsche Apoll, en grooten Spaensen Poëet Lope de Vega Carpio, opgewekt en herschapen door den kunst-lievenden en yverigen Heer Iacobus Baroces zwevende op Nederduytze wieken, voor mijne oogen verschenen, en al prikkelende zijn taalgenoot, en rust-besnijdende vrient, gedwongen, deeze zijne Gedwongen vrient mij over te dragen, om op onze Amsteldamsche Schouburgh in Neder-duytse Vaarzen te doen herleeven». 
of 34, he got married to a Sephardic girl named Esther de Oliveira and that they lived in the very heart of the city's Jewish quartier, on Vlooijenburg. ${ }^{18}$ But whoever he may have been, for sure, he had a good hand in picking theater successes. As the fourth Lope play in a row, the Gedwongen vrient was one of the most frequently performed pieces, only to leave the repertoire somewhere deep in the eighteenth century. That was, however, the end of a respectable performance history of 100 years, making this play one of the greatest Lope hits ever in Amsterdam's theater.

With the Sephardic production path now opened, the cooperation between the immigrant native speaker of Spanish and apparent connoisseur of Spanish theater on the one hand, and the Amsterdam Theater on the other, continued to be fruitful. The next year, Isaac Vos's fellow actor Leonard de Fuyter used the same construction in producing Het verwarde hof (1647). This new play was based on Baroces' prose translation of $\mathrm{El}$ palacio confuso which recent scholarly research has proved to be the work of Amescua. At the time, however, it was generally believed to be Lope de Vega's, as the title page of the Dutch play text proudly states in capitals (see Illustration 4). Moreover, the dedicatory introduction to the play develops into a great praise of the Spanish Phoenix, when, according to the rules of transfer productions, tribute is paid to all those who have been involved in the transfer: ${ }^{19}$

I offer the noblest fruits from the genius of the great Spanish poet Lope de Vega Carpio, who won the applause of one of the highest monarchs in Europe. The king was so passionate about his plays, that they became well known all over the civilized world. And so, still inexperienced in his plays, when I heard them, they moved me and touched me so much, that I took the courage to follow that God of Poets as closely as possible, in order to practice myself in his qualities. Mr Baroces, first, helped me on the way and brought me so far that I could restyle and render him into Dutch verses,

18. City Archives Amsterdam, Archiefbank, Indexen, Ondertrouwregisters use query 'Barokes'. See also Álvarez Francés [2013].

19. Cited (in English translation by the authors) from the introduction to Fuyter [1647:*1v]: «de eelste vruchten der harssenen van den grooten Spaensche Poët Lope de Vega Carpio, diese in geen kleyn aensien hebben ghebracht by den grootsten Staf-drager van Europa, die de selve so gekoetstert heeft, datse bekent en geroemt zijn in al de redelijckste deelen der werelt, daarse my noch onkundigh zijnde, door het gehoor so vervoert, en doorgrieft hebben, dat ick my heb derven verstouten, dien Godt der Poëten op de hielen te volgen, om my te oeffenen in de eygenschappen sijner wijsheden, ende eyndelijcke door den Heere Barokus soo veel te weege gebracht, dat ick de selve heb vervolmt, en gestelt in Nederduytsche vaarzen; op datse onse konstlievende (doch voornamelijck UE) mochten smaaken en behagen; op dat wy hier door moogen plucken, het geene andere gewesten ghepluckt hebben)». 
so that art lovers here may taste and enjoy what has been picked and gathered in other regions.

The fact that $E l$ palacio confuso and its Dutch translation Het verwarde hof were falsely attributed to Lope de Vega, only underscored his importance and popularity. And instantly, this play, too, became a super hit in the repertoire. After a staging frequency of nine times in the year of its premiere, this play, again, never left the stage until late in the eighteenth century. It even outlived its centennial predecessor by one decade. ${ }^{20}$

It was the same construction that, in the next year, generated Lope de Vega's greatest success ever in the Netherlands. In 1648, Jacobus Baroces and Isaac Vos once again joint forces, in the production of Beklaaglyke dwang, the Dutch version of La fuerza lastimosa. The introduction to the play text is worth citing not only for information about the transfer. It also testifies to the growing confidence in producing Spanish successes in the Netherlands. In a fresh and provocative voice, it is an open invitation to the readers and theater visitors, and challenges mainstream theater in the Netherlands with the question why one should hold on to Aristotle's classical principles or precepts for drama when a modern stage required modern drama, attractive for both eyes and ears of the people of today:

You will see a play here, that, if I am not mistaken, will please you, all the more because the creator has kept an eye on the times of his life, rather than on the ancient rules of theater. To my opinion, when writing drama plays for our own times, it does not make sense to stick to times foregone, now that the eye wants its share of what is on show, just as much as the ear. This play was translated from Spanish by mister Baroces, and composed in Dutch riming verses by me. ${ }^{21}$

20. Although immensely popular, Leonard de Fuyter's adaptation of the play El palacio confuso met with critical reviews, too. Jan Vos, one of the Directors of the Schouwburg, and a successful playwright himself, wrote this epigram: «So, you boast, you have modified Vega's play so much / That he wouldn't recognize it anymore. Well, that is not a virtue! / First it was a fine silk texture, and now it is simple textile. / You call that adapation? Consider it mutilation». Quoted from Vos [1662:390]. The Dutch verses are: «Gy hebt de Vegoos [!] spel, segt gy, so veel vermaakt / dat hy 't niet kennen kan. Maar dit wordt heel gewraakt. / Eerst was 't een zyde kleedt, nu is 't gelapt met laaken. / Is dat vermaaken? Neen. Dit houdt men voor mismaaken».

21. Cited (in translation by the authors) from the Introduction to the play text by Vos [1648:fol. A2v]: «U sult hier een spel sien, en, soo ick my niet bedriege, sal het $\mathrm{u}$ behagen, te meer, also de maker meer gesien heeft na de tijd daar in hy leefde, als wel op de oude Toneel-wetten; en het dunckt 


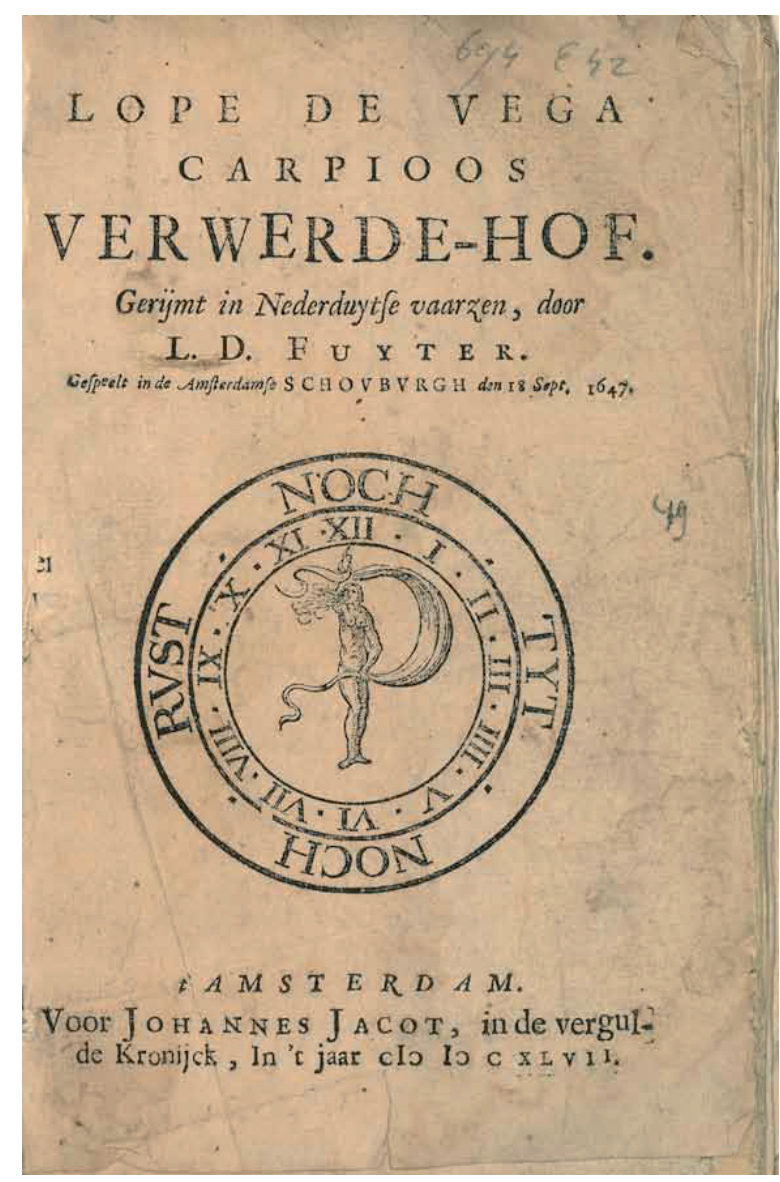

Illustration 4: El palacio confuso, attributed to Lope, as it was performed in the Amsterdam Schouwburg, in the Dutch version by the actor and playwright Leonard de Fuyter.

Obviously, the self confident abdication from Antiquity in favor of Modernity, is a theoretical reflection of Lope de Vega's own practice of theater making, articulated in the Arte Nuevo. Moreover, the fact that theoretical debates were now taken up in paratexts by Lope's Dutch ambassadors in Amsterdam, indicates that for all its entertainment and attractiveness, Spanish theater not only met with popularity in the Netherlands. Indeed, the greater its name, applauses and revenues, the fiercer also became the voices of classicist opponents, as uttered by some local playwrights in Amsterdam.

my ook ongerijmt, in het rijmen van Toneel-speelen, voor de tegenwoordige tijd, te letten op de voorledenen; nu het oog neffens de oren wil aandeel hebben in hetgeen haar vertoond werd. ' $t$ Is uyt het Spaans overgeset door den Heer Barokes, en van my op Neerduyts Rijm gebragt». 


\section{Lope's dominance over the Amsterdam stage}

Negative reactions mainly targeted the Spanish invasion of Amsterdam's theater for the fact that this type of lively dramas, or shows in the true sense of the word, would be mere crowds pleasers for their high degree of entertainment. If any starting poet and playwright wanted to be successful, and asked what plays, therefore, he should be studying and imitating, the cynical answer would be: 'Spanish plays! They are lively and emotional in their nature, and surely please the common people ${ }^{\prime 22}$ Even a local hero and playwright as renowned as Joost van den Vondel was suffering from these rivaling productions in 'his' home theater in Amsterdam. As far as the crowds were concerned, taste really seemed to be changing since "new theater was imported in those days, mostly from Spain, that in liveliness and emotions and great alterations, even though sometimes not very artful or well ordered, pleased the crowds so much (as they are easily impressed by empty words and extravagant costumes) that people preferred that copper for real gold, paying no attention to the plays of Vondel'. ${ }^{23}$

For all classicist objections against theater innovation, the performance frequencies and revenues of Lope de Vega's latest production in 1648 said it all. At its premiere, La fuerza lastimosa in its Dutch version was staged nine times. And with four more plays Lope de Vega was all over the repertoire in this most important year in the relationships between the Netherlands and Spain, when the Peace of Westphalen was concluded: on the overall number of almost 120 shows, the play list presented Lope de Vega with

22. Quote, in English translation by the authors, from the play Gelukte list of bedrooge mof written by the classicist playwright Andries Pels (printed in Amsterdam, in 1689, but written earlier in 1681). The play is a fierce defense of French classicism; the question quoted is spoken by a young and unwise starting poet. The introduction to the play, too, marks the popularity of Spanish drama, when jealously speaking of 'those wild and dis-ordered Spanisch plays, that nonetheless attract large audiences': 'die wilde en wanschikkelyke Spaansche stukken, niettegenstaande die meer volk trekken'. More contemporary quotes on the popularity of Spanish theater in Brandt [1993:455-456].

23. Quoted, in English translation by the authors, from the biography of Vondel as written by his contemporary friend Gerard Brandt [1682:68]: «[...] men met der tijdt andere speelen, meest uit het Spaensch vertaelt, invoerde, die door ' $t$ gewoel en veelerley verandering, hoewel 'er somtydts weinigh kunst en orde in was, den grooten hoop (zich aan 't ydel gezwets en den poppentoestel vergaapende) zoo behaagden, dat men kooper boven goudt schatte, en Vondels treurspeelen achter de bank wierp». 
- Beklaaglyke dwang (9 shows)

- Casandra en Karel

- Vervolgde Laura

- Gedwongen Vrient

- Verwarde Hof

These figures reveal that, on average, visitors of the Schouwburg in 1648 would see a Lope play on every sixth show day, or in other words, once every three weeks. Moreover, for its life span Beklaaglyke Dwang was to last even longer than the two evergreens that had been produced previously in the co-production of Baroces and the actor-playwrights of the Grand Theater. Lope's La fuerza lastimosa lived for well over 120 years in the Dutch drama version, and was staged in Amsterdam's Schouwburg as late as in 1768 !

With the Lope invasion at its zenith now, the next big hit entered the Amsterdam theater just half a year later. This was El cuerdo loco, staged for the first time in the early days of 1649 as the play Voorzigtige dolheit. For sure, its instant success of seven performances in two months time, was due to the vibrant popularity of Spanish drama at the time. And the attractive dramatic qualities of this play, featuring a good king Antonio who, by feigning insanity and thus uncovering the imminent coup in his treacherous court, succeeded in saving his beloved and his entire kingdom, were even enhanced by political topicality. The doom scenario of a king under threat, and falling victim of a coup, was a current reality in the nearby European kingdom of Great Britain. The anti-royalist coup, there, was coming to the climax of Charles I's decapitation in January 1649, shocking all monarchies in Europe just as much as it affected people in the Republic of the United Provinces, exactly at the time when El cuerdo loco was brought to stage in Amsterdam. ${ }^{24}$ The new drama production, therefore, was keen to admit in the introduction that theater, indeed, mirrored the stage of the world, and suggested its topicality by adding to the title the word Court-play (Hof-spel). Another novelty in the paratextual information of Spanish plays was the Latin quotation on the title page, stressing the political message in the play once more: Qui nescit simulare, nescit regnare (You

24. For the Dutch orientation on England and the analysis of Joris de Wijse's play in that context, see Helmers [2015:22]. 
can't rule if you can't feign). In consequence, the paratext focuses on the political theme, rather than giving information about the transfer process. Strongly condemning the recent regicide, the introduction expressed the wish that the scenario of this Machiavellian play had been the true outcome in England's court intrigue, with a King using fraud and feigning insanity in order to unveil betrayal: 'a Spanish Insanity, to which its poet, most correctly, had applied the word Prudent'. ${ }^{25}$ So, for its political bias and topicality, the Dutch production of El cuerdo loco, differed considerably from the mainstream Lope transfers at the time.

Unlike previous producers of Spanish plays, the playwright involved, Joris de Wijse, was not a Schouwburg actor but an Amsterdam middle class intellectual. Educated at an academic level in the city's Athenaeum Illustre, he was well trained in the literary arts and a collector of paintings. Moreover, in his professional life he was a respectable tax collector and notary. ${ }^{26}$ So, in the Schouwburg Joris de Wijse would not be an actor, but a regular visitor. Maybe, this high and more comfortable social position explains why there are no credits to Lope on the title page, nor any information on the transfer process in the introductory texts by the playwright. For a man of his qualities, any defaming voices (such as those against the actor-playwright Van Germez in the case of Laura), were less likely to be heard. It is significant, however, for the popularity of Spanish theater, that with the Voorzigtige dolheit a new type of producers appears in the transfer process. Now that the Spanish vogue was really up and running in Amsterdam, the next two decades witnessed, indeed, a range of intellectual poets and other peripheral playwrights in the city participating in the production of Spanish comedias for the Schouwburg repertoire. Moreover, some elite ladies contributed to the new genre, too, among whom Amsterdam's female star in literature Catharina Questiers, who in 1655 reworked Lope's Si no vieran las mujeres into the Dutch play text entitled Den geheymen minnaar (The secret lover), in a chique and illustrated edition. ${ }^{27}$ The statistics for

25. Quoted, in English translation by the authors, from the introduction by Joris de Wijse [1650:fol. (')4r.]: «Door een spaansche Dolheit, die haar poeet, en niet te onregt, de naam van Voorzigtigheit toepast. Maer eer op ons toneel de rollen des voorsichtigen Konings afliepen, had de gekroonde Lijdzaamheit voor haar Erfpaleis, maar op een moordtonneel haar rol gespeelt; evenwel heb ik hoewel te laat, noch willen voortgaan, om te betuygen dat ick wenschte voorgespeelt te sien, tgeen dit tonneelspel nagespeelt heeft».

26. See his biographical entry and the inventory of his paintings in the online Montias Database.

27. For Catharina Questiers and English translations of some of her poems, see Gemert [2010:286301]. The illustration for the play text is in the digital collection of the Rijks Museum Amsterdam. 
these later plays, however, indicate that after the exciting boom caused by the actor-playwrights (and Joris de Wijse, whose production even after the political momentum was kept in the repertoire for more than a century), most productions by these peripheral playwrights did not reach the popularity, performance frequencies or longevity of those initial Lope plays anymore.

Both in terms of quantity and in quality, therefore, it is fair to conclude that Lope de Vega's successful invasion into the Amsterdam Grand Theater was accomplished in a concentrated peak period of time between 1642 and 1649. Seven years did it take to make the breakthrough and bring seven Spanish top hits in the stage repertoire, each one of these exclusively taken from no other oeuvre than Lope's. In addition to the earlier adaptations made by the travelling diplomat and playwright Rodenburgh, new transfer paths were developed either through intermediaries in France and the Southern Netherlands, or via the Dutch prose translations of the Sephardic migrant in Amsterdam Jacobus Baroces, in order to facilitate the broader introduction of more Spanish playwrights who were to follow in the next two decades when Lope de Vega's plays would still be performed in a high frequency of, for example, one on three plays in 1655 , and one on five in $1666 .^{28}$

With these statistics, the Spanish Phoenix was facile princeps of the Amsterdam theater, easily outshining the drama productions of Amsterdam's local poets. Having 22 shows in 1648, Lope almost doubled that year's performance numbers of Amsterdam's prime playwright Joost van den Vondel (Gijsbreght 4, Leeuwendalers 5, Joseph 2 and Gebroeders 2). By 1655, local productions were even further behind of the foreign and foremost Spanish plays. Then, Lope's performances, alone, added up to 20, whereas Joost van den Vondel had none, Bredero had two (Moortje and Spaansche Brabander) and P.C. Hooft had one. In 1666, Lope de Vega was staged 17 times, while 3 shows presented a piece by Joost van den Vondel (Gijsbreght van Aemstel), 6 shows P.C. Hooft (3 for his Warenar and 3 for Velsen) and 1 for Bredero. In terms of creating popular hits for the theater, the Dutch playwrights in their own Grand Theater were no match to the Spanish invasion. When the Peace of Westphalen was signed in 1648, and Spain definitively gave up its territorial titles, Lope de Vega could righteously claim to be the true conquistador of the Netherlands.

28. The ONSTAGE data system reveals that in 1655, Lope de Vega's plays were performed 20 times in the overall playlist of 68 shows; for 1666 statistics are 17 on 92 shows. 


\section{ANNEX 1}

Chronological inventory of Lope de Vega Plays Produced FOR THE AMsterdam THEATER

1642 El perseguido - Theodore Rodenburgh Casandra en Karel Baldeus

1644 La escolástica celosa - Theodore Rodenburgh Jaloersche studenten

1645 Laura perseguida - (Rotrou Laure persécutée) Adam Karelsz van Germez Vervolgde Laura

1646 El amigo por fuerza - Isaac Vos Gedwongen vrient

1647 El palacio confuso (Mira de Amescua)- Leonard de Fuyter Verwarde hof

1648 La fuerza lastimosa - Isaac Vos De beklaagelycke dwangh

1649 El cuerdo loco - Joris de Wijse Voorzigtige dolheit

1655 Si no vieran las mujeres - Catharina Questiers Den geheymen minnaar

1656 La firmeza en la desdicha-Anon. Stantvastigheid in't ongeluk

1656 Las mudanzas de fortuna y sucesos de Don Beltrán de Aragón-(Rotrou Cosroes) Adriaan Bastiaansz Leeuw Kosroes

1657 La amistad pagada - Thomas Asselyn Den grooten Kurieen

1658 El molino - Theodore Rodenburgh Celia en Prospero

1659 La hermosa Ester - Johan Serwouters Hester, oft verlossing der jooden

1660 La locura por la honra - Gillis van Staveren De dolheyt om de eer

1664 La reina Juanna de Napoles - Hendrick de Graef Joanna koningin van Napels

1670 La batalla del honor - Hendrick de Graef Den dullen ammirael

1671 El mayor imposibile - Johan Blasius De malle wedding of gierige Gerard

1671 El mayor imposibile - NIL De malle wédding óf Gierige Geeraard, blyspél

1674 Los locos de Valencia - Willem G. van Focquenbroch Min in't lazarus-huys

1674 Los donaires de Matico: comedia- E.D.S.M. Spaensche comedie De mislukte liefde, en trouw van Rugero prins van Navarren

1708 Guardar y guardarse - (Lesage Don Felix de Mendoce) - Anon. Don Felix de Mendoza 


\section{WORKS CITED}

AlBACH, Ben, Langs kermissen en hoven: ontstaan en kroniek van een Nederlands toneelgezelschap in de 17de eeuw, De Walburg Per, Zutphen, 1977.

Álvarez Francés, Leonor, The Phoenix glides on Dutch Wings. Lope de Vega's «El amigo por fuerza» in Seventeenth-Century Amsterdam, Master Thesis University of Amsterdam, Amsterdam, 2013, online, http://www.scriptiesonline.uba. uva.nl/452381.

Bodiam, Miriam, Hebrews of the Portuguese Nation: Conversos and Community in Early Modern Amsterdam, Indiana University Press, Bloomington, 1997.

Boer, Harm Den, La literatura hispano-portuguesa de los sefardies de Ámsterdam en su contexto histórico-social (ss. XVII y XVIII), Doctoral Thesis University of Amsterdam, Amsterdam, 1992.

BRAndT, Gerard, «Het leven van Joost van den Vondel», in Joost van den Vondel, Poëzy of Verscheide Gedichten. Op een nieu by een vergadert, en met veele ook voorheen nooit gedrukte dichten vermeerdert: Mitsgaders een aanleidinge ter Nederduitsche Dichtkunste, en het Leven des Dichters, Leonard Strik, Franeker, 1682.

Brandt, George W., and Wiebe Hogendoorn, German and Dutch Theatre, Cambridge University Press («Theatre in Europe: a Documentary History series», no. 3), Cambridge, 1993.

Early European Books, Printed Sources to 1700, Proquest, 2016, online, http://eeb. chadwyck.com/home.do.

Fuks-Mansfeld, Renate G., De Sefardim in Amsterdam tot 1795. Aspecten van een joodse minderheid in een Hollandse stad, Historische vereniging Holland, Hilversum, 1989.

FUYTER, Leon de, Verwarde hof, Johannes Jacot, Amsterdam, 1647, online, http:// www.indu.niederlandistik.fu-berlin.de/vergleich.html?deckblatt verwerde hof vega.pdf.

Gemert, Lia van, Hermina Joldersma, and Olga van Marion, eds., Women's Writing from the Low Countries 1200-1875: A Bilingual Anthology, Amsterdam University Pres ("Amsterdam Anthologies»), Amsterdam, 2010.

Germez, Adriaen Karelsz van, Vervolgde Laura, Johannes Jacot, Amsterdam, 1645, online, https://books.google.nl/books?id=5YJjAAAAcAAJ\&printsec=frontcov er\&hl=nl\&source=gbs ge summary $\mathrm{r} \& \mathrm{cad}=0 \# \mathrm{v}=$ onepage\&q \&f=false . 
Helmers, Helmer J., The Royalist Republic. Literature, Politics, and Religion in the Anglo-Dutch Sphere 1639-1660, Cambridge University Press, Cambridge, 2015. Horn-Monval, Madeleine, Répertoire bibliographique des traductions et adaptations françaises du théâtre étranger du Xve siècle à nos jours (Part IV 1. Théâtre espagnol. 2. Théâtre de l'Amérique Latine. 3. Théâtre portugais), Centre National de la Recherche Scientifique, Paris, 1961.

JANS, Irma de, «Iets over Cornelis de Bie als navolger en plagiaris», in Verslagen en mededelingen van de Koninklijke Vlaamse Academie voor Taal-en Letterkunde, Gent, 1929, p. 139-170.

Jautze, Kim, Leonor Álvarez Francés, and Frans R.E. Blom, «Spaans theater in de Amsterdamse Schouwburg (1638-1672): Kwantitatieve en kwalitatieve anlyse van de creatieve industrie van het vertalen», De Zeventiende Eeuw. Cultuur in de Nederlanden in interdisciplinair perspectief, XXXII,1 (2016), forthcoming.

Kossmann, E.F., Nieuwe bijdragen tot de geschiedenis van het Nederlandsche tooneel in de 17de en 18de eeuw 's, Martinus Nijhoff, Gravenhage, 1915.

Losada-Goya, José Manuel, Bibliographie critique de la littérature espagnole en France au XVIIe siècle, Droz, Genève, 1999.

Marion, Olga van, and Tim VergeER, «Spain's Dramatic Conquest of the Dutch Republic: Rodenburgh as a Literary Mediator of Spanish Culture», De Zeventiende Eeuw. Cultuur in de Nederlanden in interdisciplinair perspectief, XXXII,1 (2016), forthcoming.

ONSTAGE, Online data system for Theater in Amsterdam in the Golden Age, ed. F.R.E. Blom, University of Amsterdam, online http://www.vondel.human ities.uva.nl/onstage.

Pels, Andries, Gelukte list of bedrooge mof, Albert Magnus, Amsterdam, 1689, online, https://books.google.es/books?id=7ncAAAAAcAAJ\&printsec=frontcover\& $\underline{\mathrm{dq}}=$ Gelukte + list + of + bedrooge + mof $+1689 \& \mathrm{hl}=\mathrm{es} \& \mathrm{sa}=\mathrm{X} \& \mathrm{ved}=0 \mathrm{ahUKE}$ wib9LHwlvjPAhXB2BoKHYHPAMEQ6AEIJTAA\#v=onepage $\& q=\mathrm{Ge}$ lukte $\% 20$ list $\% 20$ of $\% 20$ bedrooge $\% 20 \mathrm{mof} \% 201689 \& \mathrm{f}=$ false.

PraAg, Jonas Andries van, La comedia espagnole aux Pays-Bas au XVIIe et au XVIIIe siècle, Doctoral Thesis, University of Amsterdam, Amsterdam, 1922.

Questiers, Catharina, Den geheymen minaar, Gerrit van Goedesberg, Amsterdam, 1655, online, https://books.google.nl/books?id=Pp5lAAAAcAAJ\&lpg=PT1\&ots =WXYJXzZz1F\&dq=Den\%20geheymen\%20minnaar\%20questiers\&hl=nl\&p 
$\mathrm{g}=\mathrm{PP} 1 \% 23 \mathrm{v}=$ onepage $\& \mathrm{q} \& \mathrm{f}=$ false\# $\mathrm{v}=$ onepage $\& \mathrm{q}=$ Den $\% 20$ geheymen $\% 20 \mathrm{~min}$ naar\%20questiers\&f=false.

Rodenburgh, Theodore, Casandra hertoginne van Bourgonje, en Karel Baldeus. Treur en bly-eynde-spel, N. van Ravesteyn, for D.C. Hout-haeck, Amsteldam, 1642, online, https://books.google.nl/books?id=1pViAAAAcAAJ\&dq=rodenburgh\%20casan dra\&hl=nl\&pg=PT2\%23v=onepage \&q\&f=false\#v=onepage\&q\&f=false.

Rodennurgh, Theodore, Jaloersche studenten, bly-eyndende-spel, printed by Raves teyn for, D.C. Hout-haeck, Amsterdam, 1644, online, https://books.google.nl/ books?id=pCBbAAAAQAAJ \&d q=rodenburgh\%20jaloersche\&hl=nl\& $\mathrm{pg}=\mathrm{PT} 19 \% 2523 \mathrm{v}=$ onepage $\& \mathrm{q}=$ rodenburgh $\% 20$ jaloersche $\& \mathrm{f}=$ false $\% 23 \mathrm{v}=$ one page \&q=rodenburgh $\% 252520$ jaloersche $\& \mathrm{f}=$ false\#v=snippet\& $\mathrm{q}=$ roden burgh $\% 20$ jaloersche\&f=false.

Smits-Veldt, Mieke B., Het Nederlandse renaissancetoneel, Hes Uitgevers, Utrecht, 1991. STCN. Short Title Catalogue Netherlands, Royal Library Netherlands, Den Haag, online, https://www.kb.nl/organisatie/onderzoek-expertise/informatie-infrastr uctuur-diensten-voor-bibliotheken/short-title-catalogue-netherlands-stcn.

Vos, Isaac, Gedwongen Vrient, Jan van Hilten, Amsteldam, 1646, online, https:// books.google.nl/books?id=R-VVAAAAcAAJ\&dq=vos $\% 20 v e g a \% 201646 \& h \mathrm{l}=\mathrm{n}$ $1 \& p g=P P 4 \% 23 v=$ onepage $\& q=v o s \% 2520 v e g a \% 25201646 \& f=$ false\#v=one page \&q=vos\%2520vega $\% 25201646 \& \mathrm{f}=$ false.

Vos, Isaac, De beklaagelycke dwangh. Bly-eindend treurspel, G. Joosten, Amsterdam, 1648.

Vos, Jan, Alle de Gedichten, Jacob Lescailje, Amsterdam, 1662, online, https://books. google.nl/books?id=XoIUAAAAQAAJ\&dq=Jan\%20Vos\%20Alle\%20de\%20Ged ichten $\% 20($ Amsterdam $\% 252 \mathrm{C} \% 201662) \& h \mathrm{l}=\mathrm{nl} \& \mathrm{pg}=\mathrm{PP} 7 \% 23 \mathrm{v}=$ onepage \&q= Jan\%2520Vos\%2520Alle\%2520de\%2520Gedichten\%2520(Amster dam,\%25201662)\&f=false\#v=onepage \& $\mathrm{q}=J a n \% 2520 \mathrm{Vos} \% 2520 \mathrm{Alle} \% 2520$ de $\% 2520$ Gedichten $\% 2520$ (Amsterdam\%2C\%25201662)\&f=false.

WIJSE, Joris de, Voorzigtige Dolheit, Jan van Hilten, Amsterdam, 1650, online, https://books.google.nl/books?id=65JiAAAAcAAJ\&lpg=PT1\&ots=BI6wUC8s6 $\underline{\mathrm{x} \& \mathrm{dq}=\text { Voorzigtige } \% 20 \text { Dolheit\&hl=nl\&pg }=\mathrm{PT} 1 \% 23 \mathrm{v}=\text { onepage \&q=Voorzigtige }}$ $\% 2520$ Dolheit\& $\mathrm{f}=$ false $\# \mathrm{v}=$ onepage $\& \mathrm{q}=$ Voorzigtige $\% 2520$ Dolheit\&f=false.

Worp, Jacob Adolf, Geschiedenis van den Amsterdamschen Schouwburg 1496-1772, S.L. van looy, Amsterdam, 1920. 